
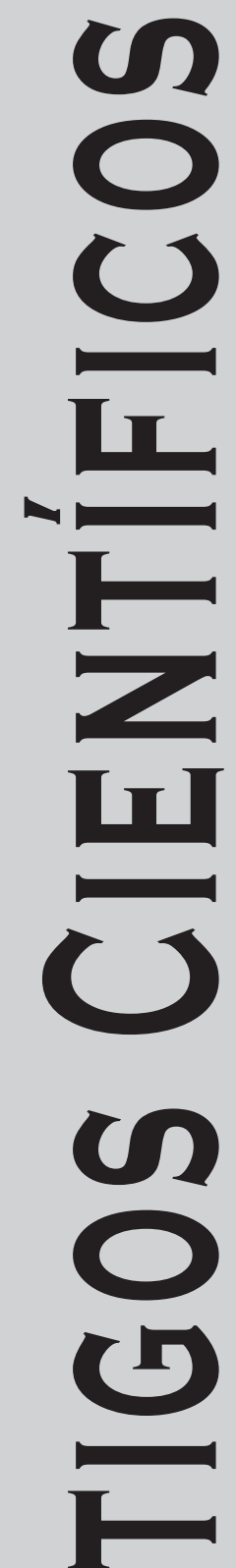
ac

Revista Música Hodie, Goiânia - V.14, 238p., n.1, 2014 


\title{
O Século da Eletrônica
}

\author{
Joel Chadabe (Universidade Yale, New Haven, Connecticut) \\ chadabe@emf.org \\ Geraldo Henrique Torres Lima (UNESPAR, Campus II - FAP, Curitiba, PR) \\ geraldohenrique@gmail.com
}

\begin{abstract}
Resumo: A história tecnológica eletrônica, sua utilização e as transformações decorrentes de seu aproveitamento na música são a tônica desse trabalho que trata dos instrumentos de produção sonora por meio eletrônico. Abrange os instrumentos que produzem sinteticamente a sonoridade de instrumentos convencionais ou daqueles que criam virtualmente qualquer som, bem como da utilização de instrumentos de registro sonoro aproveitados para fins de composição musical. Nesse contexto, aborda as grandes mudanças paradigmáticas que promovem o estabelecimento de novas estéticas.
\end{abstract}

Palavras-chave: Música; Eletrônica; Tecnologia.

The Electronic Century

Abstract: The history of electronic technology, its use and the changes resulting from its use in music, are the focus of this work that approaches the instruments of sound production electronically. Relates to instruments that produce synthetically a conventional instruments sonority or those that create virtually any sound as well as the use of sound recording instruments for musical composition purposes. In this context, addresses the major paradigm shifts that promote the establishment of new aesthetics.

Keywords: Music; Electronics; Technology.

\section{Introdução}

A entrada no século XXI e a aproximação do centésimo aniversário da música eletrônica foi estimulante para revisitar as raízes da música apoiada na eletrônica e avaliar seu percurso até o ponto onde estamos. O artigo publicado na revista norteamericana Electronic Musician (fevereiro a maio de 2001) discorre sobre instrumentos, ideias artísticas, conceitos de negócio, música, empreendedorismo e os avanços técnicos do século, desde as primeiras realizações tecnológicas ao sintetizador mais avançado. O foco está voltado para os itens tecnológicos utilizados pelos músicos em busca da expansão dos recursos antes encontrados somente em instrumentos acústicos tradicionais. Onde pertinente, documentam-se composições musicais relevantes, no tocante ao emprego desses recursos tecnológicos. Uma rica e profunda tradição é redescoberta ao modo de uma jornada. E numa linguagem simples, exibe uma visão abrangente de um momento determinante para a definição de uma nova relação entre música e tecnologia.

Um aspecto que muito chama a atenção é sua excelente qualidade como resumo histórico, aliado ao espírito comemorativo do centenário da música apoiada na eletro-eletrônica. Além disso - escrito num momento excitante de comemoração da virada de século - mostra a contínua transformação, em curto espaço de tempo, das complexas práticas musicais inerentes ao próprio desenvolvimento tecnológico da era eletrônica.

Passados poucos anos desse novo século, alguns dos prognósticos apresentados ao final do artigo já se confirmam. Observações como a de Daniel Teruggi têm tido resposta em pesquisas de espacialidade sonora que buscam dar tratamento mais realista ao aspecto da propagação do som, mesmo que ainda usando transdutores, elos frágeis na cadeia de equipamentos de áudio. Noutra observação, a de David Zicarelli, nota-se a intensificação da utilização do computador e dispositivos de síntese como o centro da cultura da industria- 
lização, o que tem sido facilitado pela crescente melhoria na capacidade de processamento de computadores portáteis e similares.

No campo do instrumento musical, visto como vasto em recursos sonoros e interativos, conforme prognosticou Craig Harris, confirma-se a tendência de instrumentos com interface desenvolvida para explorar as ações do músico com facilidade. São instrumentos com flexibilidade para reconhecimento dos gestos de um intérprete, atribuindo parte da tarefa musical ao computador. Essa natureza de instrumento com interfaces exclusivas tem acentuado a dependência cada vez maior de um software para cumprir esse papel coadjuvante.

\section{Parte I}

\section{Início da música eletrônica}

Quando teria iniciado a música eletrônica? Essa é uma questão frequentemente formulada. Teria sido em 1759, na França, quando Jean-Baptiste de La Borde construiu o Cravo Elétrico? - O Clavecin Électrique era um instrumento de teclado que empregava cargas de eletricidade estática para provocar o choque de pequenas plaquetas metálicas contra sinos. - Ou teria sido em 1874, nos EUA, quando Elisha Gray inventou o Telégrafo Musical? Em minha opinião, cada um desses experimentos e muitos outros construídos durante o século XIX, estavam apenas preparando a cena para instrumentos que viriam. A resposta mais amplamente aceita é a de que a música eletrônica iniciou por ocasião da passagem do século XIX para o século XX.

\section{Thaddeus Cahill}

Pelo final do século XIX, quando a eletricidade não estava ainda largamente disponível e os automóveis eram raros, as companhias telefônicas estavam começando a instalar seus cabos nas ruas das cidades. Foi nesse tempo que Thaddeus Cahill, um advogado e empreendedor de Washington, D.C., teve a ideia de construir um instrumento musical eletrônico e usá-lo para difundir música para residências, restaurantes e hotéis através de linhas telefônicas. Num tempo em que não existiam os meios de comunicação de massa em suportes tais como fita e disco, o Telarmônio de Cahill foi visto por muitos como a maior inovação no conceito de distribuição de música.

Os fatos desenrolaram-se rapidamente e Cahill obteve sua primeira patente assegurada para 'The Art of and Apparatus for Generating and Distributing Music Electronically'. Em 1898, ele iniciou a construção da primeira versão do instrumento que seria mais tarde chamado de Telarmônio. Tendo encontrado apoio financeiro em 1901, Cahill logo fundou a New England Electric Music Company. Em 1902, a companhia arrendou um espaço de fábrica em Holyoke, Massachusetts, onde Cahill iniciou a construção de uma versão melhorada do Telarmônio.

Diante dos resultados, em 1905, sua companhia assinou um acordo com a New York Telephone Company para estender os cabos especiais de transmissão dos sinais do Telarmônio para a cidade de Nova Iorque. Num início de noite em 1906, o Telarmônio foi desmontado e transportado para Nova Iorque, onde foi remontado no recém-criado Telharmonic Hall, na Rua 39, Broadway. O instrumento pesava aproximadamente 200 toneladas e teve de ser transportado em mais de 12 vagões ferroviários, de Holyoke ao novo destino.

O Telarmônio, instalado no piso térreo do prédio, era operado por dois músicos sentados diante de um console de dois teclados. O método de geração de som do instrumento 
era a síntese aditiva, realizada por dínamos de corrente alternada, que ficavam instalados no porão, junto a sistemas de comutação, transformadores e outros dispositivos elétricos. Ondas sinusoidais eram geradas por alternâncias das saliências de discos dentados girando próximo de bobinas indutoras. À medida que uma saliência aproximava-se da bobina, a voltagem crescia, decrescendo depois, quando a posição do espaçamento entre dois dentes encontrava-se sobre essa bobina. Diferentes discos com distintos números de dentes girando simultaneamente produziam diferentes ondas que constituíam harmônicos, determinando a frequência da onda resultante.

O Telharmonic Hall foi aberto ao público e à imprensa em 26 de setembro de 1906 e seu primeiro programa para um restaurante ocorreu em 9 de novembro de 1906: para o Café Martin, situado na Rua 26, entre a Quinta Avenida e a Broadway. No restaurante, foi um momento festivo. Casais românticos sentados à mesa eram tratados a sons de Telarmônio ouvidos de falantes especiais ocultos entre plantas.

Infelizmente, problemas começaram a acontecer durante as transmissões do Telarmônio. A programação gerada por ele, que incluía as aberturas de Rossini, ao ser transmitida pelos cabos estendidos pela Companhia Telefônica de Nova Iorque, interferia na conversação telefônica. Isso levou a companhia telefônica a encerrar o acordo de cessão dos cabos, instaurando-se uma crise. Os sócios de Cahill reagiram formando a Companhia Telharmonic Cahill de Nova Iorque e, ao mesmo tempo, procurando uma franquia da cidade de Nova Iorque para estender seus próprios cabos. Entretanto, não havia cabos disponíveis e sem cabos não havia transmissão sonora. Assim, não havia assinantes do serviço, acabando a atividade: as portas do Telharmonic Hall fecharam.

Cahill permaneceu impávido e determinado, não admitindo a derrota. Enviou o Telarmônio de volta para Holyoke, assumiu o controle da empresa e fez uma tentativa corajosa de recuperação lançando um terceiro modelo, já melhorado. Finalmente, em 1911, a franquia de colocação de cabos foi concedida mas já era tarde demais. Infelizmente, o tempo para o Telarmônio havia passado. Outros instrumentos baseados noutras tecnologias chamaram a atenção do público ao ponto de o Telarmônio não ser mais interessante. Em 1914, a empresa New York Cahill Telharmonic declarou falência, num final triste. Como engenheiro e empresário, Cahill havia levado uma ideia visionária ao seu limite. Falhou apenas porque sua ideia necessitava de tecnologia não disponível no momento. A tecnologia existiu, no entanto, para o próximo grande instrumento musical eletrônico inventado apenas alguns anos mais tarde.

\section{0 instrumento mágico}

Embora o Teremim não tenha sido vendido em quantidade que caracterizasse um mercado de massa, por outras razões, foi de um sucesso retumbante. A história do Teremim e de seu inventor, Leon Theremin, é um conto de intriga política, bem como de invenção musical. Em 1920, ainda estudante de engenharia em Moscou, Theremin construiu um instrumento muito incomum e o demonstrou aos colegas. Era uma caixa com duas antenas, uma que se estendia verticalmente a partir do topo, a outra projetando-se horizontalmente por um dos lados. Theremin manipulou seu instrumento, movendo as mãos no ar: uma movendo-se em relação à antena vertical para controlar a frequência e a outra movendo-se em relação à antena horizontal para controlar a intensidade.

Naquela época, o governo russo estava fazendo um grande esforço para introduzir energia elétrica em todo o país. Nesse contexto, por ser um instrumento eletrônico, o Teremim atraía a atenção. E foi depois de apresentar seu instrumento, em 1921, a um grupo de cientistas soviéticos, em Moscou, que Theremin foi convidado a demonstrá-lo a Vladimir 
Lênin. Levou, então, seu instrumento para uma demonstração ocorrida no escritório do líder comunista que interessou-se em experimentá-lo. Sobre esse fato, Theremin disse mais tarde que Lenin tinha ouvido musical.

É aceitável supor que o encontro no escritório de Lênin tenha sido o início do envolvimento de Theremin como um contato auxiliar para a NKVD, precursora da KGB. $\mathrm{O}$ encontro rendeu a Theremin um subsídio de viagem para demonstrar seu instrumento em toda a Rússia e depois, em 1927, o apoio para uma turnê de muito sucesso em toda a Europa. Chegando a Nova Iorque em dezembro, Theremin foi recebido como uma celebridade e lá permaneceu por dez produtivos anos, período em que conheceu Clara Rockmore, a primeira e mais conhecida tereminista.

A empresa RCA produziu teremins por um curto espaço de tempo; Leon Theremin encontrou patronos e construiu seus instrumentos; realizou trabalhos conjuntos em performances e até casou. Mas, para a NKVD, suas tarefas foram realizadas insatisfatoriamente e, em 1938, provavelmente julgando-se que ele seria mais útil em Moscou do que em Nova Iorque, agentes da NKVD o sequestraram, levando-o de volta para a Rússia. Durante a Segunda Guerra Mundial, Theremin trabalhou com radares e depois da guerra, em 1947, ele desenvolveu um dispositivo de escuta para a KGB, recebendo o prêmio Stalin de 100.000 rublos, como recompensa por seu trabalho. Em 1991, com 95 anos de idade, ele voltou aos Estados Unidos para uma breve visita, durante a qual apresentou-se na Universidade de Stanford e reencontrou velhos amigos. Leon Theremin morreu em 1993.

\section{Afinação deslizante}

Leon Theremin não foi o único a idealizar um dispositivo sem teclado que poderia produzir outras notas além das convencionais de uma escala. - Se o Teremim tivesse sido inventado na era MIDI, teria sido reconhecido como um controlador alternativo. - Embora muitos instrumentos de teclado tenham sido construídos durante os primeiros anos do Teremim (incluindo órgãos de diversos tipos, formas e tamanhos), alguns dos instrumentos mais interessantes, entre eles o Trautônio e o Ondes Martenot, foram concebidos sem um teclado em mente.

O Trautônio, desenvolvido em 1928 por Friedrich Trautwein, em Berlim, era algo como um violino de metal posicionado horizontalmente, acionado por um fio metálico pressionado contra uma barra de metal, similarmente a uma corda de violino pressionada contra a escala. Uma segunda barra de metal era usada para controle do volume e articulação de cada nota, enquanto o timbre era escolhido por manipulação de chaves independentes. Oskar Sala, que estudou com Trautwein em Berlim, desenvolveu, a partir do instrumento original, uma versão com dois teclados que chamou de Mixturtrautonium. Sala estava particularmente interessado em música para cinema e usou o dispositivo para compor música e efeitos sonoros para filmes, incluindo alguns efeitos sonoros para o filme Os Pássaros, de Alfred Hitchcock.

Maurice Martenot desenvolveu o Ondes Martenot, em 1928, em Paris. Na primeira versão, o instrumento era tocado puxando uma fita ligada a um anel que era colocado no dedo, de modo que, ao puxar a fita, a frequência era alterada em um glissando contínuo. Enquanto se puxava a fita com a mão direita, usava-se a mão esquerda para variar o volume e escolher as configurações de timbre de um banco de chaves. Atendendo a pedidos, mais tarde, Martenot incorporou um teclado ao instrumento. Também adicionou uma alavanca sob o teclado para ser operada movimentando-se o joelho - com ela o músico poderia controlar mudanças contínuas do timbre.

Nem Trautwein nem Martenot eram empresários. Eram inventores que projetaram e construíram seus instrumentos sem análise de mercado, sem planejamentos para pro- 
dução em massa e sem estratégia de negócio para sucesso de público. O Ondes Martenot, mais do que o Trautônio, teve compradores, mas era fabricado atendendo pedidos, um a um. Assim, o campo de instrumentos musicais eletrônicos que parecia ser promissor em 1930, ainda não havia sido ocupado. Primeiramente, viu-se um grande negócio falhar, depois, um instrumento inovador tornar-se bem conhecido. Alguns tiveram poucos seguidores e muitos outros passaram em total desconhecimento do público em geral.

Havia mercado para instrumentos musicais eletrônicos? Sim. E ele estava prestes a se abrir.

\section{Sucesso comercial}

O inventor Laurens Hammond preencheu essa lacuna. Ele, que projetou e manufaturou uma certa variedade de instrumentos (relógios, embaralhador automático de mesa para cartas de bridge e óculos para visualização de filme em 3-D), em 1933, comprou um piano usado e começou a projetar um órgão eletrônico.

Ao contrário de Theremin, Trautwein e Martenot - e igualmente de outros inventores de instrumentos eletrônicos motivados pela aventura da invenção e pelo fascínio pela descoberta de novas maneiras de fazer música - Hammond foi motivado pelo lucro com as vendas. Seu objetivo era vender órgãos para um mercado de massa. Como a maioria dos empresários com um objetivo similar, com olhar perspicaz, ele analisou os problemas de projeto, de fabricação, de marketing e vendas, objetivando reduzir despesas e aumentar receitas.

Os projetos para os seus órgãos refletiram a economia na fabricação. Como exemplo, depois de analisar pedaleiras côncavas de outros órgãos, Hammond projetou a pedaleira nivelada e omitiu os pedais usados com menos frequência. Os sons no seu órgão eram gerados por rodas de tom (tonewheels) que eram refinamentos dos mecanismos que produziam síntese aditiva no Telarmônio de Cahill. Com isso, seu órgão Hammond Modelo A veio a público em junho de 1935.

A estratégia de venda adotada por Hammond era persuasiva e intensa, inicialmente destinada a igrejas de todo o país. Mas o som distinto de seu órgão logo foi descoberto por músicos que apreciaram suas qualidades marcantes para o jazz, o blues e, depois, o rock. Muitos modelos diferentes seguiram-se, com diversas variantes e melhorias, para satisfazer às necessidades da clientela. O Hammond B-3, introduzido em 1936, alcançou status legendário no mundo da música. Especialmente quando combinado com uma caixa acústica Leslie, de sistema rotativo no alto-falante, o B-3 emocionou e trouxe satisfação para muitos músicos.

O órgão Hammond foi um instrumento de grande sucesso e esteve em toda parte, demonstrando a existência de um mercado de massa para os instrumentos eletrônicos. Foi, entretanto, limitado na variedade de sons que podia produzir e, na perspectiva de um inventor de instrumento musical, havia muito trabalho a ser feito.

\section{O Sackbut eletrônico - a cítara eletrônica}

Durante a Segunda Guerra Mundial, Hugh Le Caine trabalhou na área de transmissão por microondas, no Conselho Nacional de Pesquisa do Canadá, em Ottawa. Num período mais tranquilo, após a guerra, ele seguiu uma vida secreta, trabalhando em casa à noite, onde construía um instrumento musical eletrônico.

Em 1948, Le Caine terminou um protótipo de trabalho que ele chamou de 'Cítara Eletrônica', um precursor dos sintetizadores controlados por tensão que estavam por vir na década de 1960. Sua cítara era capaz de grandes nuanças de execução. Com teclas que eram sensíveis a pressão lateral para mudar a altura do som, podia-se deslizar de uma nota 
para outra. O efeito vibrato podia ser realizado deslocando-se o dedo lateralmente e as notas podiam ser projetadas até uma oitava de distância da frequência básica. A pressão vertical numa tecla controlava o volume de tal modo que ataques suaves podiam ser realizados. Ainda mais interessante, Le Caine acrescentou mecanismos que introduziam irregularidade aos tons, como sons de sopro, zumbidos ou asperezas, para melhorar o que chamou de 'pureza monótona' dos tons eletrônicos.

Depois de uma apresentação pública do Sackbut e de muitas palestras e demonstrações, o Conselho Nacional de Pesquisa do Canadá instituiu um estúdio para Le Caine. Esse estúdio lhe permitiu desenvolver instrumentos musicais eletrônicos para serem fabricados por empresas canadenses. Este fato é uma afirmação de que um mercado de música eletrônica realmente existia e que este mercado estava começando a se abrir.

\section{O sintetizador RCA}

O próximo grande dispositivo eletrônico musical focou a capacidade de produzir qualquer som. O conceito da RCA foi voltado ao desenvolvimento de um instrumento que pudesse substituir uma orquestra de estúdio e o sintetizador musical eletrônico RCA Mark II foi um passo nessa direção. O instrumento, construído por Harry Olson e Herbert Belar, nos Laboratórios Samoff da RCA, em Princeton, Nova Jersey, foi concluído em 1957.

O Mark II continha 750 válvulas eletrônicas de vácuo e cobria uma parede inteira de uma sala, horizontal e verticalmente. Era efetivamente um leitor de fita de papel perfurada que controlava um sintetizador analógico. Primeiramente, a informação era registrada nessa fita usando-se um dispositivo perfurador de rolo de papel similar a uma máquina de escrever. Depois, quando o rolo de papel passava através de um leitor, as informações eram lidas pelo contato entre hastes de metal que se tocavam através dos furos no papel, assim fechando um circuito e acionando os procedimentos para iniciar ou interromper a emissão do som.

Considerando-se o tempo em que foi construído, o Mark II era poderoso, mas sua interface de usuário era um pesadelo: era tão difícil de operar que teve apenas seu primeiro usuário. Adquirido pelo Centro de Música Eletrônica Columbia-Princeton, em 1959, foi usado quase exclusivamente por Milton Babbitt, compositor e professor na Universidade de Princeton. (Babbitt comentou tempos depois: "Eu tive a paciência de Jó”).

O Mark II ainda existe no Centro de Música Computacional da Universidade de Columbia, apesar de severamente danificado por ladrões que invadiram o estúdio em 1976.

\section{Os primeiros dias}

Em resumo, a história da música eletrônica durante a primeira parte do século 20 compreende mais o desenvolvimento dos primeiros instrumentos do que a evolução da música eletrônica. Estes instrumentos, em geral, não estiveram associados com ideias musicais inovadoras. Ao invés, eles foram continuações de uma linhagem de invenção de instrumentos geralmente destinados a reproduzir música também praticada com instrumentos tradicionais. Cahill, por exemplo, tinha a intenção de distribuir, em massa, música de variados estilos, desde aberturas de Rossini à música popular e hinos de igreja.

A maior parte desses primeiros instrumentos, incluindo o Telarmônio, não ofereciam novas possibilidades musicais aos compositores. Eles ofereceram alguns timbres novos - muitas vezes difíceis de obter - e poucos compositores de vanguarda fizeram experiências com eles. Paul Hindemith, por exemplo, compôs algumas peças para o Trautônio. Pierre Boulez e Olivier Messiaen, entre outros compositores, tiveram um interesse passageiro pelo Ondes Martenot - vale a pena notar que o Ondes Martenot ainda é ocasionalmente 
usado por compositores contemporâneos. Le Caine experimentou compor música para sua cítara, mas o seu trabalho mais consistente foi uma performance de 'Rhapsody in Blue', de Gershwin. ${ }^{1}$ Os sons do RCA Mark II foram documentados em um disco LP de demonstração feito pelos engenheiros da RCA, mas as seleções, que incluíam 'Blue Skies', de Irving Berlin, não eram músicas inovadoras.

O RCA Mark II foi excepcional em oferecer novas possibilidades musicais, possibilitando precisão de controle e substancial complexidade de ritmo e textura, além de uma grande paleta de sons eletrônicos. Estas foram qualidades que Milton Babbitt considerou importantes. 'Philomel' (1963) e 'Vision and Prayer' (1964), de Babbitt, ambas para soprano e sons eletrônicos do RCA Mark II gravados em fita magnética, são provavelmente as únicas obras-primas criadas com um desses instrumentos antigos.

De uma forma ou de outra, todos esses primeiros instrumentos prenunciaram o futuro. O plano comercial de Cahill para a Telarmônio antecipava Muzak². O Trautônio e Ondes Martenot lançaram as bases para a flexibilização da afinação e para a microtonalidade. A Cítara Eletrônica foi a precursora do sintetizador controlado por voltagem. O sintetizador RCA Mark II, com seu leitor de fita de papel perfurado, prefigurou os softwares sequenciadores da era MIDI.

O Teremim é uma exceção. Desse grupo dos primeiros instrumentos musicais eletrônicos, unicamente ele permanece viável hoje na sua forma original. Ele foi usado na música dos grupos Beach Boys, Led Zeppelin e muitos outros; seu som proporcionou fundo misterioso em filmes tais como os de Alfred Hitchcock. Hoje, ele é um instrumento mais leve e mais barato do que era no início, além de que seus mecanismos foram melhorados pela tecnologia mais recente. Entretanto, ele faz hoje exatamente o que fez quando Theremin o demonstrou em Nova Iorque, em 1927.

\section{Parte II}

\section{Estórias da fita magnética (como o gravador de fita magnética modela a música eletrônica moderna)}

Quando os gravadores de fita magnética foram introduzidos no mercado por volta de 1950, alguns compositores iniciaram uma revolução musical. A gravação magnética tornou possível registrar fontes sonoras em qualquer lugar do mundo - seja numa locomotiva na estrada de ferro em Paris ou numa loja de departamentos em Tóquio - e depois organizálos em qualquer ordem. Na verdade, o termo 'música em fita' (tape music) refere-se à música composta por sons que foram gravados em fita magnética e depois editado numa continuidade particular.

Os primeiros passos em direção a invenção do gravador tiveram lugar na Dinamarca, em 1898, quando Valdemar Poulsen desenvolveu um dispositivo para gravar o som num fio de aço. Nos anos seguintes, muitas pessoas criaram empresas para explorar a invenção de Poulsen, mas nem todas foram bem sucedidas. Pelo final dos anos 1920, algumas patentes para gravação em fita magnética já tinham sido apresentadas. Em 1935, Electrizitats Allgemeine Gesellschaft (AEG) demonstrou a primeira versão de um gravador na Exposição Germânica Anual de Rádio, em Berlim, o que ajudou a estabelecer a gravação magnética como uma tecnologia viável. Ao final dos anos 1940, Ampex, Rangertone e outras empresas estavam preparadas para fabricar gravadores, quando a empresa Minnesota Mining and Manufacturing (3M) desenvolveu uma fita magnética melhorada. 


\section{Sons encontrados}

A utilização de gravadores para criar composições musicais emergiu de uma prática iniciada nos primeiros anos do século. Ela consistia de compor usando sons 'encontrados’ ao invés de compor com sons musicais, propriamente ditos. Pelo ano 1917, em Paris, França, Jean Cocteau concebeu o balé Parade utilizando-se de sons de sirenes, de um motor a vapor e de outros dispositivos mecânicos, como também da música do compositor Erik Satie. Em 1926, George Antheil utilizou um motor de avião no palco, numa performance parisiense de seu Ballet Mécanique, recentemente revivido numa produção de Paul Lehrman, da Universidade de Massachusetts, na cidade de Lowell.

O compositor americano John Cage, no entanto, foi o primeiro a explorar sistematicamente o uso de sons não-tradicionais na música, ao estilo de Ferruccio Busoni e Edgard Varèse, que no início do século teorizaram que a música poderia incluir todos os sons. Cage disse: "Eu acredito que o uso de ruído para fazer música continuará a crescer gradualmente, até alcançarmos uma música produzida por instrumentos elétricos”. Em 1939, Cage incluiu uma série de toca-discos fonográficos de velocidade variável em sua composição Imaginary Landscape $n^{\circ} 1$. Durante os anos 1940 e 1950, Cage usou rádios, discos de vinil, latas e outras fontes sonoras não tradicionais em seus trabalhos.

\section{Música concreta}

Enquanto Cage estava amplamente interessado em execução (performance), Pierre Schaeffer, então radialista da Radio France, em Paris, estava principalmente interessado em registrar seu próprio trabalho. Em 1948, durante um curso de desenvolvimento do meio que chamou de 'som radiofônico', Schaeffer completou uma experiência importante. Ele gravou sons de locomotivas e os combinou numa composição curta chamada 'Étude aux Chemins de Fer' (Estudo às Estradas de Ferro). Antes de ter acesso a gravadores de fita, ele cortava ${ }^{3}$ os discos fonográficos ${ }^{4}$ e reproduzia vários sons simultaneamente usando toca-discos diferentes, selecionando e misturando esses sons à medida que eram reproduzidos. Ele cunhou o termo 'Musique Concrète' (Música Concreta) para descrever sua técnica de gravar e combinar sons. Com esse termo, ele esperava estabelecer o contraste entre uma forma concreta de trabalhar com os sons e uma outra forma abstrata, na qual os sons são representados por notação numa partitura musical.

Para compreender o trabalho de Schaeffer, é importante lembrar que não havia televisão em 1948 e o rádio era o teatro mais universal desse tempo. Programas dramáticos, folhetins e histórias de aventura, assim como música e notícias, foram transmitidos por rádio e os sons em programas de rádio inspiraram um alto nível de criatividade.

Schaeffer, de fato, desenvolveu a ideia de som radiofônico como uma forma de arte. Em 1948, ele concluiu mais quatro estudos de música concreta, transmitidos pela Radio France em 5 de outubro do mesmo ano. O programa, chamado 'Concert de Bruits' ${ }^{5}$ (Concerto de Ruídos), foi um enorme sucesso. Compor músicas usando sons gravados foi uma ideia estabelecida nesse tempo.

\section{O estúdio de Paris}

Encorajado pela reação positiva do público ao seu trabalho, Schaeffer solicitou e obteve apoio da administração da Radio France. Pôde, então, contratar Pierre Henry como assistente musical e Jacques Poullin como técnico. Recebeu apoio, também, para criar um estúdio especifico para composição de música concreta.

Durante os anos seguintes, Schaeffer e Henry colaboraram em vários projetos, entre eles o da Symphonie pour un Homme Seul (Sinfonia para um homem só), de 1950 - um 
dos primeiros trabalhos importantes no novo meio - e Orphée (1951), uma ópera de música concreta. Em 1951, os primeiros gravadores eletromagnéticos de fita chegaram à Radio France. Poullin projetou diferentes tipos de gravadores para criar efeitos musicais especiais e desenvolveu um sistema de espacialização que direcionava os sons para diferentes alto-falantes em torno de uma sala de concertos. O estúdio cresceu na década de 1950 e atraiu muitos compositores, entre eles, Pierre Boulez, Karlheinz Stockhausen, Luc Ferrari, Olivier Messiaen e Iannis Xenakis. Este último, em particular, produziu diversos trabalhos importantes usando técnicas clássicas da música concreta, tais como manipulação dos sons variando a velocidade da fita ou reproduzindo-os reversamente. As fontes de som em Diamorphoses (1957) incluem terremotos, aviões e sinos. Em Concret PH (1958), Xenakis modificou o som de carvão em brasa. Para Orient-Occident (1960), gravou objetos arqueados, sinos e hastes de metal, enquanto para Bohor (1962) baseou-se em sons provenientes do choque entre pulseiras e outras jóias do Oriente Médio.

Em 1958, Pierre Henry deixou a Radio France para formar um estúdio independente onde, à parte do seu trabalho profissional, ele produziu muitas peças importantes usando as técnicas da música concreta. Deles, talvez o mais interessante, devido à simplicidade de suas fontes sonoras, seja 'Variations pour une Porte et un Soupir' (Variações para uma porta e um suspiro), de 1963.

\section{0 estúdio de Colônia}

Muitos caminhos entrecruzam nesses primeiros tempos. Karlheinz Stockhausen, que chegara de Colônia, na Alemanha, para estudar no Conservatório de Paris, trabalhou no estúdio de Schaeffer. Em 1953, Stockhausen voltou para Colônia e começou a trabalhar no estúdio recém-criado por Herbert Eimert, na Rádio da Alemanha Ocidental, logo tornandose diretor e principal compositor desse estúdio.

A filosofia inicial do estúdio de Colônia foi muito diferente daquela da Musique Concrète. Enquanto em Paris os sons do mundo real eram registrados e combinados por edição, como num filme, em Colônia, a primeira ideia foi gerar os sons eletronicamente por síntese aditiva, num processo muito trabalhoso, considerando-se que o estúdio usava apenas um oscilador de onda sinusoidal. As ondas eram registradas em fita num gravador de quatro pistas e depois misturadas numa única pista noutro gravador. A mistura era devolvida para uma faixa do gravador multipista e outras ondas sinusoidais eram adicionadas sobre essa faixa, misturando-as novamente para uma pista no gravador de pista única. A essa abordagem composicional deu-se o nome de Elektronische Musik.

Stockhausen começou compondo dois estudos onde usou apenas sons eletrônicos. Em 1956, ele terminou Gesang der Junglinge (Canção dos Jovens), a primeira grande obra a ser composta no estúdio de Colônia e uma das primeiras obras-primas da música para fita magnética. Em Gesang der Junglinge, Stockhausen misturou a voz de um garoto com sons eletrônicos, de modo que as palavras variavam entre inteligíveis, completamente abstratas e musicais.

Em 1960, ele passou a compor Kontakte (Contatos), peça na qual os sons sugerem percussão e timbres de piano. Durante uma viagem ao Japão em 1966, ele compôs Telemusik (Telemúsica) com sons gravados no Japão, Bali, Saara e outros lugares. Ele modulou todos os sons, de tal maneira que as suas fontes ficassem irreconhecíveis. Em 1967, em Colônia, ele compôs Hymnen (Hinos), na qual processou eletronicamente hinos nacionais de todo o mundo. A esta altura, as técnicas de Stockhausen haviam mudado dramaticamente do trabalho com sons puramente eletrônicos para o processamento de material gravado. 


\section{A Feira Mundial de Bruxelas}

Iannis Xenakis, embora conhecido principalmente como compositor, teve um impacto particularmente não musical sobre a história da música eletrônica. Formado inicialmente em engenharia civil, ele havia trabalhado desde o final dos anos 1940 com Le Corbusier, um dos arquitetos europeus mais conhecidos da época.

Em 1956, a Philips Corporation, uma grande empresa de eletrônica com sede na Holanda, convidou Le Corbusier para projetar seu pavilhão para a Feira Mundial de Bruxelas, de 1958. Le Corbusier respondeu: "Eu vou fazer um poema eletrônico" e pediu a Xenakis para projetar o pavilhão. Xenakis trouxe, então, uma ideia baseada em parabolóides hiperbólicos. Durante a Feira Mundial, o edifício foi utilizado como uma concha para múltiplas projeções de imagens criadas por Le Corbusier e também para audição musical com um sistema que incluia 425 falantes. A música apresentada no evento, assistido por mais de dois milhões de pessoas, compreendia Concret PH, de Xenakis, com menos de três minutos de duração, reproduzida entre apresentações de Poème Electronique, de Edgard Varèse. A Philips convidara Varèse, em 1957, para criar Poème Electronique em seu laboratório de Eindhoven. Lá, ele utilizou gravações de instrumentos musicais tradicionais, percussão, sons eletrônicos, voz solo e máquinas diversas, processando todos os sons eletronicamente. Poème Electronique é definitivamente uma declaração de música concreta.

\section{New York, New York}

Enquanto o estúdio de Paris estava começando no final dos anos 1940, Louis e Bebe Barron $^{6}$ criaram um pequeno estúdio comercial em Nova Iorque, onde compuseram várias trilhas sonoras eletrônicas para filmes, entre elas uma para o conhecido filme Planeta Proibido, em 1956. Os Barron já haviam trabalhado com John Cage em 1951, logo que os gravadores de fita tornaram-se disponíveis e Cage interessou-se em explorar maneiras de utilizá-los para compor música. Cage criou o projeto 'Música para Fita Magnética' financiado pelo arquiteto e amigo Paul Williams e em seguida começou a trabalhar com os Barrons para formar uma grande e variada biblioteca de sons gravados em fita magnética. Inicialmente, ele trabalhou com David Tudor e depois com Earle Brown para cortar e unir esses sons numa composição em fita: Williams Mix, trabalho realizado no sótão da casa de Cage em Lower East Side, a sudeste de Manhattan. Para isso, Cage cortou as fitas em pedaços pequenos e, em seguida, jogou cara-ou-coroa com moedas para decidir como emendálos. Com este método, Cage e Brown finalizaram Williams Mix. Depois, trabalharam juntos em Octeto Brown e, em 1954, o projeto Música para Fita Magnética foi encerrado, em parte por razões econômicas e em parte porque Cage voltou-se para outros projetos.

Enquanto John Cage e Earle Brown emendavam pedaços de fita em Manhattan, outros eventos se desenrolavam cidade afora. Em 1952, na Universidade de Columbia, Vladimir Ussachevsky apresentou um concerto que incluía suas primeiras composições eletrônicas. Pouco depois, ele começou a trabalhar com o compositor Otto Luening, em Bennington, Vermont, como também em várias salas e estúdios de Nova Iorque.

Em 28 de outubro de 1952, Ussachevsky e Luening apresentaram um concerto de sua música no Museu de Arte Moderna de Nova Iorque - fato importante por ter sido o primeiro concerto público de música em fita nos Estados Unidos. O programa incluiu Sonic Contours (Contornos Sônicos), de Ussachevsky, e Fantasy in Space (Fantasia no Espaço) de Luening. Depois disso, os dois mantiveram-se ocupados com aparições em rádios, concertos, delegações e bolsas de pesquisa. Esta onda de atividade os levou à criação de um estúdio de música em fita na Universidade de Columbia, em 1955. O estúdio floresceu e, em 1959, ob- 
teve o apoio da Fundação Rockefeller. Nele, Ussachevsky, Luening e Milton Babbit, professor de Princeton, estabeleceram o Centro de Música Eletrônica de Columbia-Princeton que adquiriu o sintetizador de música eletrônica RCA Mark II. O centro também abrigava três estúdios de gravação em fita onde, nos dez anos seguintes, mais de sessenta compositores de onze países estiveram trabalhando. Entre eles estava Mario Davidovsky, que chegou da Argentina em 1960 e tornou-se um dos compositores mais importantes da música em fita. A obra Synchronisms $n^{o} 5$ (1969), de Davidovsky, baseada numa interação entre sons eletrônicos em fita e percussionistas ao vivo, é um bom exemplo de seu estilo. Synchronisms $n^{\circ} 6$, para piano e fita, ganhou o Prêmio Pulitzer de música em 1971.

\section{De lá para Milão}

O concerto de Ussachevsky e Luening no Museu de Arte Moderna de Nova Iorque gerou consequências importantes. Luciano Berio, de Milão, Itália, então em visita a Nova Iorque, estava na platéia e animou-se com as possibilidades do novo meio. Quando voltou para a Itália alguns meses depois, conheceu o compositor e regente Bruno Maderna e juntos decidiram trabalhar explorando o potencial da música em fita. Em 1955, criaram o Studio di Fonologia, na Radio Televisione Italiana (RAI), em Milão.

O trabalho mais conhecido de Berio saído do Estúdio de Milão foi Omaggio a Joyce (Homenagem a Joyce), concluído em 1958. Berio pediu a sua esposa, Cathy Berberian, para recitar Ulisses, de James Joyce, a partir do capítulo 11. Depois, ele processou as palavras eletronicamente e as manipulou com o gravador. É de particular interesse a forma como ele misturou diferentes versões do mesmo som para produzir sons que sugerem os significados de outras palavras.

Muitos outros compositores trabalharam no estúdio de Milão. Henri Pousseur compôs Scambi (Trocas) em 1957, filtrando o ruído branco. Em 1958, John Cage visitou Milão e compôs uma versão em fita de sua antiga composição Fontana Mix, usando números aleatórios para determinar o comprimento dos segmentos de fita. (Enquanto estava lá, Cage distinguiu-se por aparecer num programa de televisão italiano de perguntas e respostas, respondendo corretamente sobre cogumelos.)

\section{O fim do começo}

John Cage continuou seu trabalho inovador nos anos 1970. Em 1972, ele compôs Gaiola de Pássaro, justapondo registros sonoros de aves de aviários aos sons do próprio Cage cantando Mureau (uma antiga composição sua, baseada em escritos de Thoreau) e sons do meio ambiente, gravados aleatoriamente.

Em 1979, Cage compôs Roaratorio, a música que utilizou o maior número de sons dentre todas as composições em fita - um verdadeiro jogo de encaixe com a qual assinalou o fim de uma era. Nela, Cage gravou, coletou e combinou aleatoriamente todos os sons que James Joyce menciona em Finnegans Wake. Na performance, as fitas foram tocadas enquanto Cage lia sua própria versão recomposta de Finnegans Wake, ao mesmo tempo que músicos irlandeses tocaram sua música popular tradicional. Roaratorio reuniu uma enorme variedade de sons de fechamento de portas (de Dublin) e mais um rio fluente, um copo colocado sobre um balcão e um carro que passava na rua - tudo reunido como música.

A ideia de usar fita para justapor sons de qualquer fonte, em qualquer combinação, era algo tão poderoso que estúdios de fita rapidamente foram formados em todo o mundo. A primeira rodada de trabalho ocorreu não apenas em Nova Iorque, Paris, Colônia e Milão, mas também em estúdios formados em Londres, Tóquio, Buenos Aires, Toronto, Estocolmo e em muitos outros lugares. 
Foi um momento marcante na história da música em que, para muitos compositores, parecia que tudo era possível. Em todo o mundo eles compartilhavam o objetivo comum de criar um novo tipo de música baseada na disponibilidade de todos os sons.

\section{Parte III}

\section{Computadores e sintetizadores analógicos}

O gravador eletromagnético, tendo se tornado disponível comercialmente por volta de 1950, provocou uma revolução musical porque possibilitou aos compositores gravar sons e dar-lhes uma ordenação qualquer. Ao longo dos anos 1950 e 1960, os avanços tecnológicos levaram muitos compositores a perceber as possibilidades musicais dos sons gravados em fita. Para esses compositores, o objetivo era compor o próprio som e, para isso, computadores e sintetizadores analógicos proporcionaram os meios de produção.

\section{Os primórdios da síntese eletrônica e a música auxiliada por computadores}

O primeiro som gerado por computadores foi ouvido em 1957 nos Laboratórios Bell Telephone, em Murray Hill, Nova Jersey. Max Mathews acabara de escrever Music I, o primeiro programa para gerar sons com auxílio de um computador. Esse seu programa foi então usado para tocar uma composição de 17 segundos do colega Newman Guttman. A peça não ganhou nenhum prêmio de música, mas garantiu o importante lugar de ter sido a primeira composição musical auxiliada por computador, marcando o nascimento da síntese sonora digital.

John Pierce, chefe do departamento no qual Mathews trabalhava, estava interessado nas possibilidades da síntese sonora. Com Pierce apoiando seu trabalho, Mathews e seus colaboradores mantiveram atualizações do programa Music I por vários anos seguintes, resultando na série de programas conhecida como Music-N: Music II (1958), Music III (1960), Music IV (1962) e Music V (1968), o último da série.

Music V era modular e hierárquico na sua estrutura. O software simulava osciladores, misturadores, amplificadores e outros módulos de áudio - cada módulo era referido como um gerador de unidade. O módulo oscilador funcionava lendo formas de onda de uma tabela numérica e produzindo cadeias numéricas que representavam essas formas de onda. Saídas numéricas de dois módulos osciladores, por exemplo, poderiam ser juntadas num módulo misturador de duas entradas. A saída desse misturador, por sua vez, poderia ser dimensionada por um módulo amplificador - multiplicada por um número fixo de aumento da sua amplitude se o multiplicador fosse maior do que 1 e diminuindo a sua amplitude se o multiplicador fosse inferior a 1. Na linguagem do Music V, uma combinação específica de geradores de unidade era chamada de instrumento, um som era chamado de nota e uma sequência de notas era chamada de parte musical.

Outros trabalhos de música auxiliada por computador estavam sendo desenvolvidos no Instituto de Tecnologia de Massachusetts, por Ercolino Ferretti, e na Universidade de Princeton, por Hubert Howe, Jim Randall e Godfrey Winham, que introduziu algumas melhorias ao Music IV. Durante os primeiros anos, no entanto, a evolução da música auxiliada por computador estava centrada nos Laboratórios Bell ou em torno dele. Em meados da década de 1960, esse campo começou a se expandir quando novos centros foram estabelecidos na Universidade de Stanford, Universidade de Columbia e noutros lugares. Com a síntese sonora apontando uma importante direção para a pesquisa musical, o domínio da música computacional continuou a crescer nos anos 70. Como se desejasse sublinhar a im- 
portância desta nova tecnologia, o governo francês criou, em Paris, o Instituto de Pesquisa e Coordenação de Acústica e Música (IRCAM), em 1977, para o qual Jean-Claude Risset, que havia trabalhado com Max Mathews nos Laboratórios Bell nos anos 60, foi nomeado chefe do departamento de música computacional.

\section{Primeiros trabalhos em computador}

A pesquisa em música computacional nos Laboratórios Bell e noutras instituições proporcionaram o pano de fundo para a primeira rodada do trabalho musical criativo com computadores. Desde o início, John Pierce e Max Mathews estavam ansiosos para fazer contato com músicos e em 1961 Pierce contratou o compositor James Tenney para trabalhar nos Laboratórios Bell. Tenney trabalhou lá de 1961 até 1964 concluindo várias composições durante esse período. Sua primeira composição foi Analog \#1: Noise Study (Análogo 1: Estudo de Ruído), concluída em 1961 e inspirada nos padrões de ruído aleatório que ele ouviu no Túnel Holanda, em seu trajeto diário entre Manhattan e Nova Jersey. O seu interesse na aleatoriedade nesse momento incluiu a utilização do computador para tomar decisões musicais e para gerar som. Em Diálogo (1963), Tenney utilizou métodos estocásticos para determinar a sequência de sons. Ele continuou a desenvolver suas ideias estocásticas em Phases (for Edgard Varese), de 1963, onde diferentes tipos de sons são combinados estatisticamente. Sua técnica resultou em sons com texturas em contínuas mudanças, similarmente a um tecido fabricado com vários materiais, formas e cores.

Em 1963, Mathews publicou um artigo influente em música computacional, na revista Science, intitulado ' $\mathrm{O}$ computador digital como um instrumento musical'7. JeanClaude Risset, na época um estudante de física na França, lendo o artigo, ficou tão animado com o potencial da música computacional que decidiu escrever a sua tese com base em pesquisas que planejava fazer nos Laboratórios Bell. Risset foi para lá em 1964 e começou a pesquisar sobre timbre, voltando para a França em 1965. Em 1967 ele voltou aos Laboratórios Bell, completando sua suíte Little Boy (1968) e Mutações (1969). Ambas contêm sons que não poderiam ter sido produzidos por qualquer outra fonte, senão por um computador.

Enquanto isso, na Universidade de Stanford, em 1963, John Chowning também motivou-se pelo artigo de Max Mathews a estudar ciência da computação. Chowning visitou os Laboratórios Bell no verão de 1964 e saiu com cartões perfurados para o Music IV. Posteriormente, estabeleceu um laboratório de música computacional na Universidade de Stanford, com David Poole. O laboratório acabaria por se tornar o Centro de Pesquisa Computacional em Música e Acústica (CCRMA), um importante centro de pesquisa da música computacional. Chowning, mais tarde, passou a desenvolver modulação de frequência (FM), como um método para a geração de som. Sua abordagem de FM foi licenciada pela Yamaha em 1974, tornando-se a base de produção de som de grande parte dos sintetizadores Yamaha dos anos 1980.

As primeiras composições de Chowning foram Sabelithe (1971) e Turenas (1972), ambas simulando sons em movimento no espaço. Depois, ele utilizou a Secção Áurea para determinar o espectro sonoro em Stria (1977), cujos resultados foram de um outro mundo: mágico, gelado, estranho e diferente de tudo o que se poderia imaginar vindo de um instrumento acústico ${ }^{8}$.

\section{À espera de um som}

James Tenney, Jean-Claude Risset e John Chowning estão entre os primeiros compositores a trabalhar com computadores nos anos 1960. Muitos outros também o fizeram nas duas décadas seguintes, incluindo Charles Dodge, Barry Vercoe, Jonathan Harvey, Larry 
Austin, Denis Smalley e Paul Lansky. Comparando-os com os compositores que trabalham com os atuais sistemas computacionais interativos, esses pioneiros tinham uma atividade árdua. Demandava-se deles conhecimento técnico, perseverança, paciência e capacidade de lidar com momentos de frustração. Muitas vezes, mediu-se em dias ou semanas o período de tempo entre especificar uma ideia musical no computador e a audição dos resultados correspondentes. Um trabalho de criação para o Music V era acumulado pelo compositor numa fita digital ${ }^{9}$, segundo a segundo, dia a dia. Quando a composição era concluída, a fita digital era levada a um departamento específico no Bell Labs, onde era convertida em sinais analógicos e gravada em fita magnética de áudio. Um processo que poderia levar até duas semanas para ser concluído.

Um problema sério nessa forma de trabalhar era o fato de os compositores não poderem ouvir os sons durante os procedimentos de um trabalho, enquanto o criavam. Muitos músicos da época, incluindo aqueles que foram atraídos para a eletrônica, não queriam lidar com os longos tempos necessários à tarefa de gerar música em computador. Outro problema significativo foi a necessidade e obrigação de os compositores e músicos saberem programar os computadores.

\section{Nascimento do sintetizador}

Os sintetizadores analógicos trouxeram a solução para um grande problema: tornaram possível um mundo novo de sons sem a necessidade de conhecimentos de programação. Eles também foram projetados para o desempenho e fornecimento de respostas imediatas, semelhante à capacidade de desempenho de instrumentos musicais tradicionais. Apesar de sintetizadores serem baseados em novas tecnologias, muitos músicos os acharam atraentes porque mantinham formas e características familiares. O crédito ao invento de sintetizadores analógicos é dado a três homens que trabalharam nisso independentemente, em 1964: Robert Moog (em Trumansburg, Nova Iorque), Paul Ketoff (em Roma) e Donald Buchla (em San Francisco).

Naquele ano, Robert Moog convidou o compositor Herb Deutsch para visitar seu estúdio em Trumansburg. Moog o conhecera um ano antes, ouvindo sua música - seguindo a sugestão do compositor, construira módulos eletrônicos de música para lhe apresentar. No momento que Deutsch chegou para a visita, Moog criara protótipos de dois osciladores controlados por tensão e Deutsch tocou com os dispositivos por alguns dias. Moog considerou os experimentos de Deutsch tão interessantes musicalmente, que em seguida construiu um filtro controlado por voltagem. E por um lance do acaso, Moog foi convidado em setembro daquele ano para a Convenção AES em Nova Iorque, onde apresentou o trabalho 'Módulos de Música Eletrônica'. Diante do interesse, vendeu seus primeiros módulos de sintetizador para o coreógrafo Alwin Nikolais e ao final dessa convenção, Moog entrara na atividade comercial de sintetizadores.

Também em 1964, Paul Ketoff, engenheiro de som da RCA Italiana, aproximou-se de William O. Smith, que dirigia o estúdio de música eletrônica American Academy, em Roma, com a proposta de construção de um pequeno sintetizador performático para o estúdio da academia. Smith consultou Otto Luening, John Eaton e outros compositores, no momento, residentes da academia. Smith aceitou a proposta de Ketoff que entregou seu sintetizador Synket (de Synthesizer Ketoff) no começo de 1965.

O terceiro dos inventores, Donald Buchla, tinha começado a trabalhar com Morton Subotnick e Ramon Sender no San Francisco Tape Music Center. Depois de projetar e construir um gerador de onda controlado por sensores ópticos, Buchla concebeu um sintetizador controlado por voltagem, com um sequenciador analógico incorporado. Subotnick e 
Sender solicitaram e receberam uma pequena bolsa da Fundação Rockefeller para custear a construção do sintetizador de Buchla que foi entregue ao Centro de Música em Fita nos primeiros meses de 1965. Buchla trabalhou intensamente com Subotnick durante todo o ano de 1965 para refinar o sintetizador, de modo que ao final daquele ano haviam desenvolvido o modelo que Buchla chamou de Série 100. Em 1966, ele formou a empresa Buchla \& Associados, começando a vender o seu Sistema de Música Eletrônica.

\section{Tecnologia dos primeiros sintetizadores}

Os primeiros sintetizadores analógicos eram constituídos por sistemas modulares controlados por tensão - um conjunto de módulos separados, cada um com uma determinada função de controle ou de áudio. Os módulos de áudio incluíam osciladores, geradores de ruído, filtros e amplificadores. Com esta técnica, o compositor ligava os osciladores em configurações de modulação por frequência ou amplitude para gerar formas de onda complexas e, em seguida, concentrava-se em elementos sonoros dentro da forma de onda, usando filtros para subtrair parciais. - Os sons dos primeiros sintetizadores, de modo geral, eram gerados por síntese subtrativa.

Os controladores típicos desse tempo incluíam geradores de envelope e teclados. Buchla empregou sequenciadores analógicos em seus primeiros sistemas já em 1965, enquanto Moog começou a incorporá-los somente em 1968. Os sequenciadores analógicos operam gerando uma série de tensões. O nível de tensão de cada etapa na série é controlada independentemente através de um botão. Cada etapa é então executada em sequência, uma após a outra, utilizando um oscilador para controlar o tempo. O sequenciador Moog, por exemplo, tinha 24 estágios configurados em três fileiras de oito estágios. Às vezes, os sequenciadores eram usados para automatizar os aspectos de desempenho, mas o mais comum era o uso de um teclado controlador para tocar um sintetizador analógico modular. Tensões geradas pelo teclado controlavam as frequências dos osciladores e filtros e, a cada vez que uma tecla era pressionada, o teclado disparava um gerador de envelope que normalmente controlava o filtro e o amplificador.

\section{Primeiros trabalhos em sintetizador}

O projeto específico de cada sintetizador - o tipo de teclado que é usado, por exemplo - é optimizado para uma abordagem musical e performance particular.

O sintetizador Moog foi o mais tradicional dos três primeiros sintetizadores porque seu teclado se assemelhava ao teclado de um piano tradicional em tamanho e operação. As teclas tinham aproximadamente o mesmo tamanho que as de um piano e o móvel era feito de madeira. Como se estivesse desejando verificar a funcionalidade do teclado Moog tradicional, Wendy Carlos usou um sintetizador Moog para gravar Switched-On Bach (1968).

O Synket foi um pouco menos tradicional do que o Moog e muito mais compacto e portátil. O teclado é menor do que o de um piano e cada tecla poderia ser movida lateralmente para até dobrar a frequência. O pianista e compositor John Eaton, vendo imediatamente seu potencial, começou a usar o Synket como um instrumento de performance. Em 1965 Eaton compôs Canções Para R.P.B., para soprano, piano e Synket. E em abril daquele ano - possivelmente a primeira apresentação pública usando um sintetizador - Eaton acompanhou a soprano Michiko Hirayama num concerto na Academia Americana em Roma.

O sistema modular Buchla foi o menos tradicional dos três sintetizadores. O teclado era constituído por uma série de tiras metálicas de posições fixas sensíveis por capacitância, cada uma gerando tensão quando tocada. Morton Subotnick, que havia desempenhado importante papel no projeto do sintetizador de Buchla, usou-o abundantemente. 
Em 1966 Subotnick mudou-se para Nova Iorque e lá a Nonesuch Records o encarregou de criar uma série de obras especificamente para lançamento de gravações. Ele trouxera um sintetizador Buchla que usou para compor Silver Apples of the Moon (1967) - primeira da série - The Wild Bull (1968) e Touch (1969). Sua abordagem para compor música foi pouco convencional, tendo em conta que não tocou suas composições num teclado, mas sim automatizando a maioria dos detalhes em sequenciadores. Nestas composições, Subotnick atuou mais como um regente, orientando os sequenciadores a cada momento, ligando-os ou desligando-os, alterando as conexões e apertando botões.

\section{$\mathrm{Na}$ direção do sucesso}

O trabalho de Subotnick cruzou a linha que separa música-arte da música-comercial porque teve seu trabalho direcionado pela encomenda de uma gravadora comercial, especificamente para aparecer em gravações vendidas por ela. Grande parte da música para sintetizador criada nesses dias tornou-se popular. Switched-On Bach, de Wendy Carlos, tornou-se o hit de 1969 e um dos best-sellers das gravações de música clássica. Depois de ouvir Chris Swanson, Robert Moog e outros executarem um concerto de jazz em 1969, no Museu de Arte Moderna de Nova Iorque, Keith Emerson comprou um sistema modular Moog pequeno utilizado para gravar a canção Lucky Man, no álbum Emerson, Lake and Palmer. Eric Siday também usou um sintetizador Moog para compor um tema para a CBS.

A demanda dos músicos, no que era claramente um mercado em crescimento, levou à formação de um grande número de empresas e desenvolvimento de novos produtos. Peter Zinovieff formou a EMS em Londres e com David Cockerell e Tristram Cary produziu o VCS-3, entre outros sintetizadores e dispositivos. Robert Moog, Bill Hemsath e outros desenvolveram o Minimoog portátil, o primeiro sintetizador comercialmente bem sucedido. Perto de Boston, Alan R. Pearlman fundou a ARP Instruments e produziu o modelo modular ARP 2500, seguido pelo modelo integrado e portátil ARP 2600. Tom Oberheim fundou a Oberheim Electronics e projetou o Four Voice, o primeiro sintetizador polifônico do mercado. Dave Smith fundou a Sequential Circuits e desenvolveu o Prophet-5, um sintetizador analógico com controles digitais. Muitas outras empresas e produtos surgiram e desapareceram. Os anos 70 viram o mercado de instrumentos musicais eletrônicos expandir acompanhado pela sensação de que eles provocariam um impacto profundo na forma como os músicos pensariam o som e a música.

\section{Parte IV}

\section{As sementes futuras da música eletrônica}

No final da década de 1960, dois caminhos distintos, mas paralelos, de inovação técnica, atravessaram o campo da música eletrônica. Um deles, conduzindo em direção a um futuro áudio digital e processamento de sinal digital, foi o da música auxiliada por computador (computer music) que não era um caminho fácil a seguir, musical e tecnicamente. Mas as dificuldades de desenvolvimento do fazer musical por computador, tais como a falta de monitoramento sonoro em tempo real e a necessidade de se especificar a música em código de computador, foram compensados pela promessa de criar qualquer som imaginável, para não mencionar as vantagens de um controle preciso, repetibilidade e a quase indestrutível capacidade de armazenamento.

O outro caminho do progresso técnico, seguido por muitos músicos, levou ao desenvolvimento do sintetizador. Os sintetizadores analógicos, muitos dos quais podiam ser 
manipulados como instrumentos tradicionais, abriram um novo mundo de som eletrônico para o desempenho musical. Com a ajuda de gravações em disco, de enorme sucesso, tais como 'Switched-On Bach' (Wendy Carlos) e o compacto simples 'Lucky Man' (Keith Emerson), os sintetizadores foram se tornando padrão instrumental para praticamente todos os conjuntos musicais populares.

\section{Sintetizadores dos anos 1970}

Pelo início da década de 1970, ficou claro que os sons eletrônicos eram atraentes e que a música eletrônica poderia tornar-se uma viabilidade industrial. É fato que o mercado explodiu durante essa década, com muitas empresas novas desenvolvendo novos instrumentos, enquanto o desenvolvimento tecnológico avançava rapidamente. Com a substituição de transistores (anos 60) pelos circuitos integrados (anos 70), os computadores e sintetizadores analógicos tornaram-se mais baratos e mais fáceis de usar - e muitas vezes eles foram agrupados em sistemas que eram chamados híbridos.

Em vários estúdios, incluindo aqueles experimentais da Bell Telephone Laboratories em Murray Hill (New Jersey) e do Instituto de Sonologia em Utrecht (Holanda), os computadores foram usados como sequenciadores sofisticados, gerando tensões que controlavam sintetizadores analógicos. Phosphones (1971), de Emmanuel Ghent e Appalachian Grove (1974), de Laurie Spiegel, são exemplos musicais criados no Laboratório Bell; Output (1979), de Gottfried Michael Koenig, exemplifica a música composta no Instituto de Sonologia.

A tendência mais importante dos anos 70, no entanto, foi a crescente acessibilidade à tecnologia digital. Com a invenção dos sintetizadores digitais, os caminhos analógico e digital que tinham seus traçados separados na paisagem da música eletrônica nos anos 60, começaram a convergir. Estes novos instrumentos combinaram as capacidades de desempenho dos sintetizadores analógicos com a precisão encontrada nos computadores.

Em 1972, Jon Appleton foi diretor do Bregman Studio, do Dartmouth College, que abrigava um grande sistema modular Moog. Appleton consultou Sydney Alonso, um membro do corpo docente da Escola de Engenharia Thayer de Dartmouth, sobre o uso de um computador para controlar o sistema. O conselho de Alonso foi o de esquecer o Moog e construir um sintetizador digital. Juntos, Alonso e Appleton construíram o Sintetizador Digital Dartmouth, para o qual Cameron Jones, um estudante da faculdade, escreveu o software. Alonso e Jones, em seguida, fundaram uma empresa chamada New England Digital que, tendo Appleton como consultor musical, passou a criar o Synclavier.

O Synclavier foi um sistema de computador e sintetizador digital com teclado e painel de controle elegantemente desenhados. Em setembro de 1977, eu comprei o primeiro Synclavier, embora o meu tenha vindo sem o teclado especial e painel de controle que Alonso e Jones haviam tão meticulosamente projetado. Minha ideia era escrever meu próprio software e controlar o computador de várias maneiras, com uma série de diferentes dispositivos. Por exemplo, em Follow Me Softly (1984) eu usei o teclado do computador para controlar o Synclavier em uma improvisação estruturada com o percussionista Jan Williams. Em 1983, Appleton compôs Brush Canyon para um Synclavier com o teclado e painel de controle.

No final dos anos 70, os sintetizadores digitais estavam em desenvolvimento em instituições de pesquisa, tais como Bell Labs e as organizações parisienses Groupe de Recherches Musicales (GRM) e Institut de Recherche et Coordination Acoustique/Musique (IRCAM). O mercado estava abarrotado de sintetizadores analógicos, híbridos ou totalmente digitais, baterias eletrônicas e dispositivos afins. Estes produtos foram fabricados por uma grande quantidade de empresas, entre elas a ARP, Crumar, E-mu Systems, Kawai, Korg, 
Moog Music, Oberheim Electronics, PPG, Rhodes, Roland, Sequential Circuits, Simmons, Synton e Yamaha. A tecnologia desse setor estava avançando rapidamente; o nível de criatividade era alto e um novo mercado de massa foi surgindo, enquanto para isso o preço era um fator cada vez mais importante. Produtos high-end foram rapidamente adaptados com vistas à expansão de mercado. Quando a empresa Fairlight Instruments colocou no mercado o primeiro gravador de amostragem (sampler), em 1979, ele custava cerca de 25.000 dólares. Em 1981, o modelo Emulator da empresa E-mu foi vendido por 10.000 dólares. Foi um tempo de muita agitação, quando novos e poderosos equipamentos surgiam a preços cada vez mais acessíveis.

\section{O começo da interface MIDI}

Embora inovação, criatividade e aventura estivessem no ar ao final da década de 70, houve também um certo caos no mercado. Não havia padronização e quando alguém comprava um sintetizador de um fabricante, tinha que comprar outros produtos dessa mesma empresa para manter a compatibilidade. O mercado estava fragmentado, mas não o suficiente para justificar um grande investimento. Na opinião de Ikutaro Kakehashi, presidente da Roland, a padronização era necessária para fazer a indústria crescer. Com um mercado mundial unificado por um padrão digital, qualquer empresa de qualquer tamanho poderia desenvolver e vender seus produtos com sucesso.

Em junho de 1981, Kakehashi propôs a ideia de uma padronização a Tom Oberheim, fundador da Oberheim Electronics. Oberheim então conversou com Dave Smith, presidente da Sequential Circuits, fabricante do bem sucedido sintetizador Prophet-5. Naquele mês de outubro, Kakehashi, Oberheim, Smith e representantes da Yamaha, Korg e Kawai reuniramse para discutir a ideia em termos gerais.

Num documento apresentado em novembro de 1981 na mostra AES em Nova Iorque, Smith propôs a ideia de estabelecer um padrão digital. No show NAMM em janeiro de 1982, Kakehashi, Oberheim e Smith convocaram uma reunião que contou com a presença de representantes de vários fabricantes. As empresas japonesas, juntamente com Sequential Circuits, foram as principais forças de retaguarda para manter o interesse no projeto e, já em 1982, definiram a primeira especificação técnica do que veio a ser conhecido como Musical Instrument Digital Interface, ou MIDI. Na mostra NAMM de janeiro 1983, um Roland JP-6 foi ligado a um Prophet 600, da Sequential Circuits, para demonstrar a funcionalidade da nova especificação MIDI. Depois de alguns aprimoramentos, ocorreu o lançamento do MIDI 1.0 em agosto de 1983.

A adoção de MIDI foi impulsionada principalmente por interesses comerciais, o que significava que essa especificação representava conceitos instrumentais familiares para o mercado de massa. Por esse mercado estar mais acomodado com teclados, MIDI era basicamente uma especificação projetada para ativar e desativar sons pressionando teclas, o que era uma séria limitação para alguns músicos. Mas a maioria deles achava que os benefícios do novo sistema MIDI superavam suas deficiências.

\section{Da síntese FM às amostragens}

Em termos empresariais, MIDI foi um estrondoso sucesso. Seu formato universal permitiu que qualquer empresa nova ou já estabelecida, grande ou pequena, pudesse apresentar ao mundo um conceito original de música. Em 1983, a Yamaha apresentou o primeiro sintetizador MIDI enormemente bem-sucedido. O DX7 foi um sucesso, não só por causa de sua implementação MIDI, mas também porque parecia ótimo e era vendido a preços razoáveis, por menos de US \$2.000. O DX7 gerava tons utilizando o sistema de modulação em 
frequência (FM) que John Chowning tinha desenvolvido na Universidade de Stanford em 1971 e depois licenciado pela Yamaha, em 1974.

A síntese FM ocorre quando a amplitude de uma onda, chamada moduladora, é usada para modular a frequência de uma outra forma de onda denominada portadora. À medida que se aumenta a amplitude da moduladora, o espectro da portadora propaga-se para incluir mais parciais. E, à medida que a frequência da moduladora muda, surgem alterações nas frequências parciais, no espectro da portadora. Em outras palavras, alterando a amplitude ou a frequência da moduladora, um intérprete pode alterar a largura de banda do espectro e o timbre dos sons. A vantagem inicial da síntese FM consiste em que controles simples podem promover grandes mudanças, tornando instrumentos como o DX7 muito populares para performances ao vivo.

Ao longo dos anos 80, a Yamaha continuou a desenvolver novas aplicações de síntese FM na linha de instrumentos, enquanto que muitas outras empresas - Akai, Korg e Roland entre outras - desenvolveram seus próprios sintetizadores. Roland, por exemplo, divulgou o Juno 106 em 1984 e a família do D-50 em 1987. Para um número cada vez maior de músicos, no entanto, a principal desvantagem da música sintetizada era soar artificialmente eletrônica. Como se vê, a maioria dos músicos MIDI queriam sons emulados. E eles se voltaram para samplers (amostradores), o que permitia que qualquer som, seja riff de trompete ou ruído de tráfego, fosse gravado e depois reproduzido a partir do toque de uma tecla.

No início dos anos 80, E-mu Systems rompera a primeira grande barreira de preço do mercado de samplers com o seu Emulator de US\$10.000. Em 1984, Ensoniq introduziu o Mirage por menos de US \$ 1.300. E em 1989, o E-mu baixou essa faixa de preço ainda mais: seu Proteus, um dispositivo reprodutor de amostragem (sample-playback) trazia 256 amostras pré-gravadas numa interface extremamente simples, custando menos de US \$1.000. A indústria voltada para a música eletrônica continuou a crescer ao longo dos anos 1980 e pelo início dos anos 90, o mercado estava repleto de sintetizadores, samplers, e outros equipamentos MIDI. Paralelamente, a atenção estava começando a se voltar para o desenvolvimento de software.

\section{O início dos softwares}

A indústria de softwares MIDI já havia surgido em meados dos anos 80. Opcode Systems, por exemplo, estabeleceu-se em 1984, com um sequenciador MIDI para o Macintosh e quase imediatamente expandiu sua linha de produtos para incluir o complemento de software editor para DX7 desenvolvido por David Zicarelli. Ao mesmo tempo, outras empresas foram se formando e produzindo softwares similares, entre elas Steinberg Research, em Hamburgo (Alemanha) e Mark of the Unicorn, em Cambridge, Massachusetts (EEUU).

Como os computadores pessoais ficaram mais rápidos e os sequenciadores MIDI baseados em computadores menos onerosos e mais comuns, outras aplicações de software MIDI foram desenvolvidas. Em 1985, Laurie Spiegel escreveu Music Mouse, um software que continha os algoritmos de geração de harmonia. Em 1986, Zicarelli desenvolveu dois aplicativos, M e Jam Factory, para a empresa Intelligent Music, para a qual continuou a desenvolver outros programas interativos de composição durante os anos seguintes. $\mathrm{O}$ aplicativo $\mathrm{M}$ era de particular interesse: uma interface de ícones musicais controlava algoritmos. Com uma dada melodia ou outra entrada, um compositor poderia usar M para gerar um fluxo infinito de variações rítmicas e melódicas, terminando com algo distinto e original. Por exemplo, eu compus 'Depois de Algumas Canções', um grupo de composições curtas de improviso para eletrônica e percussão, utilizando M para transformar alguns temas favoritos de jazz. 
Em 1985, Miller Puckette foi ao IRCAM para desenvolver softwares para o 4X, um sintetizador construído por Giuseppe di Giugno. Em meados de 1988, Puckette desenvolveu uma linguagem gráfica de controle modular que ele chamou de Max. Mais ou menos ao mesmo tempo, Zicarelli tendo visto uma demonstração de Max e, depois, a discutindo com Puckette, desenvolveu-a como um produto comercial, primeiro como Inteligent Music que depois, em 1990, teve a direção alterada pela Opcode Systems. Max foi lançado no final de 1990 e continua a ser uma ferramenta essencial para muitas aplicações personalizadas de software de música.

Os primeiros softwares de áudio digital também foram desenvolvidos em meados dos anos 80. Entre eles estavam MacMix, escrito por Adrian Freed em 1985, e Sound Designer, um produto da Digidesign lançado no mesmo ano. Em 1986, trabalhando em conjunto com uma empresa chamada Sistemas de Mídias Integradas, Freed acrescentou um dispositivo de hardware específico e o chamou de sistema Dyaxis. Em 1988, aproveitando-se do aumento de velocidade dos computadores, maiores discos rígidos e conversores DA (digital-analógico), Digidesign lançou Sound Tools, estabelecendo um padrão industrial da edição de áudio. O áudio digital foi rapidamente se tornando acessível aos músicos.

\section{As tendências para os anos 90}

Tudo expandiu por toda a década de 1990. O mercado ficou repleto de sintetizadores cada vez mais sofisticados, samplers, baterias eletrônicas, geradores de efeitos e uma enorme variedade de módulos, cada um deles fazendo algo diferente e oferecendo possibilidades sonoras únicas. Um grande mercado secundário adequava-se às necessidades de profissionais oferecendo partes adaptáveis e equipamentos gerenciadores MIDI em racks. As aplicações de software, incluindo sequenciadores, editores de fragmentos sonoros, processadores de efeito e sistemas de gravação em disco rígido, também permearam o mercado. Na verdade, havia tanto para aprender que frequentemente se ouvia a seguinte piada: "O que é uma banda? Três rapazes lendo um manual."

Alguns músicos podem ter sentido nostalgia do equipamento analógico e seus sons, mas os anos 1990 foram a década digital impulsionada em grande parte pela disponibilidade de microprocessadores cada vez mais rápidos. Não é de surpreender como os computadores pessoais foram ficando mais rápidos e mais poderosos, enquanto o áudio digital tornou-se cada vez mais baseado em software.

Os avanços da década de 1990 vão muito além da simples edição de som. O Processamento de Sinal Digital (DSP), que possibilita a compositores transformar, bem como sintetizar sons, tornou-se um componente importante em sistemas de áudio digital. Uma das aplicações DSP mais completas a aparecer no final dos anos 90 foi MSP, criado por Miller Puckette e David Zicarelli e comercializados por Cycling '74, uma empresa que Zicarelli fundou em 1997 para desenvolver o software DSP, bem como para tornar o software M novamente disponível.

Entre os pioneiros no uso de sistemas de DSP (Processamento de Sinal Digital) para compositores está Carla Scaletti que, em 1986, criou um sistema de síntese (software) que ela chamou Kyma (palavra grega que significa onda). No ano seguinte, ela ampliou Kyma e incluiu Platypus, um acelerador de áudio (hardware) construído por Kurt Hebel e Lippold Haken que ficava acoplado a um computador Macintosh, recebendo instruções e gerando som. A composição sunSurgeAutomata (1987) de Scaletti demonstra a capacidade algorítmica e de processamento de som do Platypus. Em 1990, Scaletti e Hebel atualizaram o hardware num novo sistema chamado Capybara. Em 1991, eles fundaram a Symbolic 
Sound Corporation, lançando o primeiro sistema Kyma completo, disponível inicialmente para o Mac e logo em seguida para o PC. Com o seu hardware evoluindo e suas atualizações contínuas, Kyma continua a ser um dos mais poderosos sistemas de design de som disponíveis hoje.

\section{Olhando para o século 21}

Ao olharmos para o futuro, é difícil prognosticar quais inovações terão o maior impacto em nossas vidas e em nosso trabalho. Embora possamos supor que a tecnologia de áudio digital continue a melhorar à medida que aumenta a potência de computadores e caem seus preços, prever exatamente como isso vai ocorrer em nossos estúdios não é fácil. Perguntei a várias figuras de destaque no campo da música tecnológica sobre seu pensamento sobre o que as próximas décadas trarão e aqui estão alguns desses prognósticos.

Craig Harris (compositor, autor e editor executivo do Leonardo Electronic Almanac): "Novos instrumentos terão uma enorme flexibilidade tanto na esfera sonora como nos modos de interação, de tal forma que os compositores poderão criar da maneira que for mais eficaz para eles, artistas poderão realizar obras de modo que funcionem melhor para os seus próprios estilos pessoais, de modo que os membros da audiência possam se beneficiar de uma rica variedade de interpretações. Esta é uma região que distingue os instrumentos eletrônicos dos instrumentos tradicionais, na medida em que não há nenhum campo sônico preconcebido ou um método para a interação que seja inerente à máquina. Pela primeira vez, temos instrumentos que terão seus limites estabelecidos mais pela nossa imaginação do que pelas leis da acústica."

Carla Scaletti (compositora, desenvolvedora de software e presidente da Symbolic Sound Corporation): "O que parece nos interessar é o processo de fazer música. Gravações não oficiais em turnês de improvisações do material de um álbum original são mais procurados do que os álbuns acabados. Alguns músicos estão começando a publicar versões MP3 de 'obras em andamento' na Internet, por isso todos nós podemos testemunhar e participar do processo de exploração e refinamento que vai para o álbum acabado. Cada álbum lançado gera imediatamente uma descendência múltipla em forma de remixes. Ambientes interativos e imersivos, como jogos de computador exigem músicas que possam sofrer interferências numa multiplicidade de formas; cada caminho através dos resultados dos jogos resultam, então, numa nova peça musical. O século 21 será o ‘século da composição', onde 'objetos' (como álbuns acabados) estarão praticamente livres na Internet, enquanto que os criadores desses objetos serão muito procurados."

Daniel Teruggi (compositor e diretor do Groupe de Recherches Musicales, Paris): "Se ativarmos nosso ouvido de analista, veremos ainda uma grande diferença entre um som gravado e o som produzido e propagado por um dispositivo acústico. Alto-falantes, microfones, sistemas de amplificação e conversão digital são os elementos de processamento de som que ainda têm muito para atingir, naquilo que eu chamaria de uma imagem mais realista do som."

David Wessel (pesquisador e diretor do Center for New Music and Audio Technologies da Universidade da Califórnia, Berkeley): “Os processadores de uso geral tais como PowerPC e Pentium são capazes de síntese de música em tempo real e processamento. Laptops estarão no centro da escolha para processamento de sinal de síntese, o cerne da nova instrumentação de música eletrônica orientada para a performance. Estou confiante de que veremos também o desenvolvimento de uma nova geração de sistemas de detecção de gestos, tendo a música em mente, incluindo uma série de interfaces comuns, como as de 
desenho em tablets e controladores de jogos adaptados para o controle íntimo e expressivo de material musical. Eu vejo e estou começando a ouvir o surgimento de uma música eletrônica que pode ser mais semelhante à música de câmara ou de um pequeno grupo de jazz onde o diálogo musical e a improvisação desempenham papéis essenciais.”

David Zicarelli (desenvolvedor de software e presidente da Cycling 74): "Computador, sintetizador e gravador tornaram-se os novos instrumentos folclóricos de culturas industrializadas, substituindo a guitarra. Um número esmagador de registros é agora produzido no gênero música eletrônica e não há nenhum sinal de que isso vai parar tão cedo."

Você pode estar se perguntando como tirar proveito dos recursos disponíveis presentemente e nos próximos anos. Comece pensando que tipo de música você quer realizar e quais as ferramentas para melhor ajudá-lo a alcançar seus objetivos. Explorando a Web e lendo revistas especializadas conhecerá novos desenvolvimentos em hardware e software. Acima de tudo, aprender a história: ler livros sobre o assunto e ouvir gravações de estudos realizados pelos pioneiros, bem como pelos ativistas atuais. Uma tradição de cem anos está esperando para ser explorada e quanto mais você souber sobre o passado, melhor você poderá moldar o seu próprio futuro.

\section{Notas}

1 N.T.: Trata-se de um registro, durando um minuto, da parte de clarinete de Rhapsody in Blue, de Gershwin, usando o Sackbut para produzir sons de onda quadrada.

2 N.T.: Serviço de distribuição musical adotado em estabelecimentos comerciais, geralmente em elevadores.

3 Corte é o termo usado para o processo de registro do som sulcando o disco matriz de acetato.

4 N.T.: Os discos eram cortados em 'loop’ (voltando ao mesmo ponto), sistema chamado por ele de sillon fermé.

5 N.T.: A obra 'Cinq Études de Bruits' (Cinco Estudos de Ruídos) compreende os estudos: n 1 Déconcertante ou Étude aux tourniquets; $\mathrm{n}^{\circ} 2$ Imposée ou Étude aux chemins de fer; $\mathrm{n}^{\circ} 3$ Concertante ou Étude pour orchestre; $\mathrm{n}^{\circ}$ 4 Composée ou Étude au piano; $n^{\circ} 5$ Pathétique ou Étude aux casseroles.

${ }^{6}$ N.T.: Louis Barron e Bebe Barron são considerados pioneiros da música eletroacústica nos Estados Unidos e autores da primeira obra para fita magnética realizada no país.

7 N.T.: MATHEWS, M. V. The Digital Computer as a Musical Instrument. Science 1 November 1963: 553-557.

${ }^{8}$ N.T.: Ao referir-se a instrumento acústico, o autor trata dos instrumentos em que a produção sonora é mecânica e convencional.

9 N.T.: As fitas eram de papel perfurado.

\section{Referências}

CHADABE, Joel. Electric Sound: The Past and Promise of Electronic Music. New Jersey: Prentice Hall, 1996.

COLBECK, Julian. Keyfax - Omnibus Edition. Milwaukee: Hal Leonard Corp., 1996.

LEHRMAN, Paul D. e TULLY, Tim. MIDI for the Professional. (s.l.): Amsco Publications, 1993.

ROADS, Curtis. The Computer Music Tutorial. Cambridge: MIT Press, 1996.

WEIDENAAR, Reynold. Magic Music from the Telharmonium. Lanham, MD: Scarecrow Press, 1995.

YOUNG, Gayle. Sackbut Blues. Otawa: Canadian National Museum of Science and Technology, 1989. 


\section{Referências audiovisuais}

Para complementar informações, as indicações de registro de áudio e vídeo estão separadas por parte:

\section{Parte I}

- The Art of the Theremin (Delos) - Clara Rockmore executa transcrições de músicas compostas por Rachmaninoff, Saint-Saens, Stravinsky entre outros.

- Oskar Sala: Subharmonische Mixturen (Erdenklang) - músicas de vários compositores, incluindo Paul Hindemith, para oTrautônio.

- Les Ondes Musicales (SNE) - Genevieve Grenier executa Debussy, Ravel, Faure, Gaubert e Satie em Ondes Martenot.

- Milton Babbitt (CRI) - inclui o trabalho "Vision and Prayer" com a soprano Bethany Beardslee e sons do sintetizador musical eletrônico RCA Mark II.

- Clara Rockmore: The Greatest Theremin Virtuosa (Big Briar), produzido por Robert Moog e Big Briar - contém interpretações e demonstrações de Clara Rockmore em ambiente de conversa informal com Robert Moog e Tom Rhea.

\section{Parte II}

- John Cage 25-Year Retrospective Concert (Wergo) - Imaginary Landscape no. 1 e Williams Mix do Projeto Música para Fita Magnética.

- Forbidden Planet (GNP Crescendo), de Louis and Bebe Barron - trilha sonora original do filme de ficção (1956).

- Pierre Schaeffer: L’Oeuvre Musicale (EMF Media) - contém todos os trabalhos musicais de Schaeffer, incluindo as colaborações com Pierre Henry.

- Xenakis: Electronic Music (EMF Media) - contém todos os trabalhos antigos de Xenakis.

- Pierre Henry (Harmonia Mundi, France) - contém Variations pour une Porte et un Soupir, um dos trabalhos mais elegantes dos primórdios da 'musique concrète'.

- Elektronische Musik 1952-1960 (Stockhausen Verlag) - contém Gesang der Junglinge e Kontakte, de Karlheinz Stockhausen.

- Hymnen (Stockhausen Verlag), de Karlheinz Stockhausen - esplora hinos nacionais do mundo como fonte material.

- Mikrophonie I e II; Telemusik (Stockhausen Verlag), de Karlheinz Stockhausen - contém sons da Ásia e outras partes.

- Electro Acoustic Music Classics (Neuma) - contém Poème Electronique, de Edgard Varèse, apresentado na Feira Mundial de Bruxelas, em 1958.

- Electronic Music Pioneers (CRI) - contém os trabalhos de Vladimir Ussachevsky e Otto Luening apresentados no Museu de Arte Moderna de Nova Iorque, em 28 de Outubro de 1952. 
- Henri Pousseur (BV Haast), incluindo Scambi, composta em 1957, em Milão.

- Berio/Maderna (BV Haast) incluindo Omaggio a Joyce, de Berio, baseda no texto Ulysses, de James Joyce.

- Bird Cage, de John Cage, (EMF Media) - contém o maior trabalho de colagem de John Cage, baseado em sons de pássaros gravados em aviários.

- Roaratorio (Wergo), de John Cage, incluindo uma leitura de Cage, músicos irlandeses tocando e cantando, complementado com todos os sons mencionados em Finnegans Wake, de James Joyce.

- Pauline Oliveros: Electronic Works (Paradigm) incluindo I de IV e outras antigas composições em que usou fita magnética.

- I Am Sitting in a Room (Lovely Music), de Alvin Lucier, usando gravadores de fita magnética e ressonância do ambiente para transformar palavras em sons abstratos.

- A Sound Map of the Hudson River (Lovely Music), de Annea Lockwood, que contém sons do rio Hudson desde sua nascente nas montanhas Adirondack até a baía Lower Bay da cidade de Nova Iorque e oceano Atlântico.

\section{Parte III}

- John Chowning (Wergo) - destaca as primeiros trabalhos de música para computador.

- Columbia-Princeton Electronic Music Center 1961-1973 (New World) - contém Earth's Magnetic Field, de Charles Dodge.

- Jean-Claude Risset (INA-GRM) incluindo Mutations, composta no Bell Labs, como também Inharmonique e Sud, compostsa depois.

- Jean-Claude Risset (Wergo) exibindo Computer Suite from Little Boy, como também Sud e outras composições para computador e instrumentos convencionais.

- Morton Subotnick (Wergo) incluindo Silver Apples of the Moon e The Wild Bull.

- James Tenney Selected Works 1961-1969 (Artifact) - contém as composições que Tenney concluiu no Bell Labs.

\section{Parte IV}

- After Some Songs (Deep Listening) contém 'Abstractions of Jazz Standards, for computer and percussion', de Joel Chadabe.

- CDCM Computer Music Series, volume 3 (Centaur) - contém Sun Surge Automata, para Platypus, de Carla Scaletti.

- CDCM Computer Music Series, volume 6 (Centaur) - contém Brush Canyon, para Synclavier, de Jon Appleton.

- CDCMComputer Music Series, volume 24 (Centaur) - contém Follow Me Softly, para Synclavier e percussão, de Joel Chadabe, também, Música para Clarinete e ISPW, de Cort Lippe.

- Computer Music Currents 2 (Wergo) - contém Phosphones, de Emmanuel Ghent, composta no Bell Labs, em 1971. 
- Gottfried Michael Koenig (BVHaast) - contém Output, composta por Koenig, no Instituto de Sonologia, em 1979.

- Women in Electronic Music 1977 (CRI) - contém Appalachian Grove, de Laurie Spiegel, composta no Bell Labs, em 1974.

Joel Chadabe - Compositor, autor e pioneiro no desenvolvimento de sistemas musicais interativos. Concertista desde 1969, apresentando-se internacionalmente em festivais. Presidente da Intelligent Music entre 1983 a 1994 , foi responsável pela elaboração e publicação de uma vasta gama de softwares inovadores e historicamente importantes, incluindo M e Max. Co-autor de Roger Meyers no desenvolvimento de PLAY, o primeiro sequenciador software. É autor do livro ‘Electric Sound: The Past and Promise of Electronic Music’ (1996).

Geraldo Henrique Torres Lima - Mestre em Musicologia pela USP e desenvolve pesquisas na área de música e tecnologia, tanto da era mecânica quanto eletrônica. É professor adjunto na UNESPAR/FAP, com vínculo estatutário permanente e membro do Conselho Universitário. 